\title{
Lobbyists as Interest Group Entrepreneurs: The Mobilization of Union Veterans
}

\author{
Scott Ainsworth, University of Georgia
}

Numerous scholars view the late 1800 s as a period of considerable party influence and little group influence. I show that in the area of pension policies for Union veterans, entrepreneurial group politics thrived in the late 1800 s and rivalled party influence. A rational choice framework is used to analyze the ability of a lobbyist entrepreneur to profit from the complex interactions between Union veterans, Congress, the Pension Bureau, and the Grand Army of the Republic (GAR). I argue that lobbyist entrepreneurs operate with recognition of the opportunities for delegation from individuals to the group and from legislators to bureaus and groups. The viability of the group's linkage function depends upon the entrepreneur's abilities to master the intricacies of delegation.

Arnold $(1982,97)$ argues that interest group research is "theory rich and data poor," suggesting that some of our accepted truisms may rest on a flimsy foundation. This is especially true of research pertaining to the late 1800 s when interest group representation before Congress is assumed to have been meager and ineffective (Herring 1929) largely because of the considerable influence of parties. ${ }^{1}$ Such assumptions about group representation are difficult to refute because there is little reliable data from the 1800 s. Yet in one area where reliable data do exist-pension policy for Union veterans-the evidence suggests that group entrepreneurship was highly effective and group representation well organized. ${ }^{2}$

The entrepreneurial lobbying activities of pension attorney George E. Lemon led to the resurgence of the Grand Army of the Republic (GAR) and epitomized strong group influence. ${ }^{3}$ Largely due to the entrepreneurial efforts of Lemon, the GAR (representing Union veterans and pensioners) became the most powerful and broadly based interest group in the United States in the 1880 s with a membership that peaked at over four hundred thousand. Unlike earlier work examining entrepreneurial efforts, I specify three distinct arenas within which lobbyist entrepreneurs operate. Lemon established vital relationships in three distinct political arenas: (1) the GAR's membership pool, (2) elected officials, and (3) rival organizations. The connections across these arenas are complex. Entrepreneurs expending efforts in one arena (e.g., by directly lobbying legislators) must rely on the rational

SCOTT AINSworth is Assistant Professor of Political Science at the University of Georgia.

The American Review of Politics, Vol. 16, Summer, 1995: 107-129

@1995 The American Review of Politics 
responses of individuals in the other arenas (e.g., veterans filing claims). Such complex interactions are mitigated if lobbyist entrepreneurs recognize the opportunities for facilitating individuals' access to government officials (e.g., see Brown and Jankowski 1994).

Within each of the three distinct arenas, the lobbyist entrepreneur must overcome a substantial problem. For instance, in the first arena the lobbyist must overcome the collective action problem and attract and retain members. In the second arena, lobbyists must persuade elected officials to act in a particular way. Finally, in the third arena lobbyists may have to compete with rival organizations (either groups or parties). The rationale for the lobbyist entrepreneur to operate across the arenas is straightforward. In order to influence the policy making of elected officials, a lobbyist entrepreneur must establish a forceful constituency within the electorate, which requires that the collective action problem be resolved and that rival organizations not dominate the policy process. Simultaneous strategic interaction across these three arenas is an important aspect of entrepreneurial politics that has been overlooked in the interest group literature, which has tended to focus more narrowly on interactions within one or two arenas.

A lobbyist's successes in one arena can insure favorable reactions in the other arenas and the overall success of the entrepreneur requires at least a modicum of success in each of the arenas. Success in these separate arenas requires that the lobbyist entrepreneur capitalize on opportunities that arise from others' desires to delegate authority or work through an intermediary. The entrepreneur's ultimate success is marked by an electoral connection, linking legislators' actions and constituents' support. ${ }^{4}$ Unlike the earliest rational choice approaches to interest groups, in which lobbying is a public good provided after the resolution of the collective action problem (e.g., Olson 1965), in this work lobbying plays a crucial role in the establishment of a group. In Olson, lobbying is a "by-product" of the sale of selective incentives, rather than a central element of the group's development. In contrast to Hansen's conclusion that individuals join a group "in response to collective benefits" $(1985,93)$, the GAR's resurgence was based primarily on the organization's abilities to facilitate members' pension claims and to guide members through an increasingly complicated pension process.

In the next section, I review some of the literature on group entrepreneurs and establish a theoretical framework for the paper. In the middle sections of the paper, I discuss Lemon's entrepreneurial activities related to the GAR's membership pool, rival organizations, and government officials. In the last section of the paper, the emergence of the GAR's independent, group influence is discussed. 


\section{Literature Review: \\ A Theoretical Background for Lobbyist Entrepreneurs ${ }^{5}$}

Earlier work on interest group lobbyists often focused on strategic interactions within one or two arenas. For instance, Olson (1965) focused on the attraction of members through the sale of selective incentives in light of the opportunities to free-ride on public goods. However, by focusing so narrowly on collective action problems in the membership arena, governmental lobbying remained an inexplicable "by-product" of other group activity. In their contributions to the study of the participation paradox and organizational maintenance, Clark and Wilson (1961) and Wilson (1973) expanded the types of benefits an organization might provide, including material, solidary, and purposive rewards. Hardin (1982) argued that collective action problems were actually coordination problems that could be resolved under many circumstances through "contracts by convention." Rather than argue that collective action problems were not impediments to organization, Hardin maintained that rational individuals have clear incentives to coordinate means to obviate collective action problems. More recently, Ainsworth and Sened (1993) explored the role of interest group entrepreneurs in the coordination of solutions to collective action problems by focusing on interactions within two arenas or, in their words, "audiences."

Using Wilson's expanded typology of benefits, Salisbury (1969) analyzed lobbyists' activities in two distinct arenas: exploring lobbyist entrepreneurs' interactions with members and rival organizations. For Salisbury, successful entrepreneurship required minimizing internal organizational strain and competing well with rival organizations. Though alert to the importance of government sponsorship for some agricultural groups, Salisbury was careful to note that he did not intend to write an interest group theory of politics $(1969,2)$, and so, once again, the interaction between lobbyists and governmental officials was not a key concern. Paralleling Salisbury's concern for group entrepreneurs' competition with rival organizations, Hansen contended that group successes in the agricultural policy network stemmed from legislators' recognition of the "competitive advantages [of groups] over other intermediaries" such as local elites, party officials, or the media $(1987,190)$. In contrast to the competitive advantages garnered by groups in Hansen's work, Bauer, Pool and Dexter (1968) developed a picture of anemic influence peddlers in their study of legislators' interactions with groups and lobbyists.

Either implicitly (e.g., Olson; Hardin) or more explicitly (Ainsworth and Sened; Hansen 1987; 1991; Salisbury), interest group scholars have acknowledged that there are different types of interest representation and 
that successful group representation of interests supplanted an earlier form of interest representation. A fundamental turning point in representation during the late 1800 s and early 1900 s highlights the importance of interest group entrepreneurship. Herring (1929) was one of the first group scholars to note the fundamental and lasting change in the representation of private interests in the U.S. Congress around the turn of this century. Quite simply, though private interests channeled through individual petitions to legislators had been well represented, there was little group representation before Congress in the nineteenth century. Though there was clear recognition of the importance of interests and association with like-minded people (see e.g., Petracca 1992), member based groups as we now understand them played a limited role in national policy making. Individuals' private concerns were heard, but not because they were voiced by interest groups or interest group lobbyists. Paralleling the relative lack of nationally oriented interest groups, congressional policy was very localized after the Civil War and before the turn of the century (e.g., Stewart 1989; Sundquist 1981). Pension policy was especially fragmented. Indeed, many individuals' pensions were approved through private legislation, rather than as part of a comprehensive policy.

By the turn of the century, a new type of interest representation had emerged. In Group Representation Before Congress Herring noted that the "'old, sly, furtive, pussy-footed agents of special privilege trusts' . . . [had] been pushed to one side" (Herring 1929, 41), and responsible group representation replaced the corrupt lobbying practices of robber barons. With new lobbying, the "Washington offices of the associations, societies, leagues, institutes, boards and federations organized on a national scale . . . form[ing] the great lobbies" (Herring 1929, 41). The old style of lobbying for an individual's concerns was eclipsed by new, group lobbying for broadly based concerns. ${ }^{6}$ Under the new style of lobbying, group lobbyists and group entrepreneurs played crucial roles.

The motivation behind individuals' petitions and the old style of lobbying for narrow, private concerns was immediate self-interest. Simply ascribing the same motivation to the success of new, interest group lobbying is problematic because interest group lobbying is prone to collective action problems. The collective action problem forces one to consider interest group lobbying as something other than the aggregate of numerous individuals with shared attitudes and a willingness to make claims upon others (cf., Truman 1951). That is, the movement away from the old to the new style of representation was dependent on the resolution of the collective action problem. In light of the collective action problem, it is especially important to understand the role of lobbyist entrepreneurs during the movement from the old to the new style of lobbying. 
In the remainder of the paper, I examine the entrepreneurial activities of George E. Lemon as he interacted with the GAR's membership pool, rival organizations, and government officials. With the assistance of Lemon and the GAR, pensioners made the shift from the old style to the new style of interest representation.

\section{The Membership Pool}

Lemon's success with the membership pool was directly related to the activities of the GAR, the procedures for securing a pension, and the roles of claims agents.

\section{The Early Years of the Grand Army of the Republic}

Though traditionally aligned with the Republican Party, the GAR posed a quandary for the Republicans. Fearing a backlash from close affiliation with a militaristic group, the Republican party sought to disassociate itself from the GAR in the late 1860s. Representative John Alexander Logan (R-IL), head of the GAR from 1868 through 1870, continued to ask for money from the party because the "organization of the GAR has been and is being run in the interest of the Republican party," but no money came (Dearing 1952, 176. The emphasis is in the original letter from Logan to William E. Chandler, chair of the Republican party.). To get out the vote for Ulysses S. Grant in 1868, the Republican party formed the Boys in Blue society so that the "bloody shirt" could be waved without the militaristic overtones of the GAR The GAR was generally supportive of Grant's bid for the presidency, but both the GAR and the Republican party were careful to avoid activity that might suggest that there was any military intrigue behind the election of Grant. ${ }^{7}$

The GAR of the late 1860 s slowly replaced its military emphasis with philanthropic goals and shunned its traditional political goals. The GAR had sought the equalization of bounties, jobs through patronage, and a stop to reconstruction relief-lest the rebels be made pensioners. After Grant's election in 1868 , efforts to attain these goals were stopped. The GAR even declined to represent pensioners before Congress. During the last year of Logan's leadership, the GAR attempted to be seen as a bipartisan organization that rested "simply and grandly on its cornerstone of benevolence and patriotism" (Dearing 1952, 133). The new GAR organized popular campfires and pushed for the official recognition of Memorial Day. "In their search for devices to attract soldiers, Grand Army officers remained indifferent to the possibilities of a campaign for favourable veterans' legislation; 
[and] they refused to support the demands of pension agents" (Dearing $1952,213)$.

The combination of their early radicalism and their later aversion to anything "political" contributed to the downfall of the GAR after 1868 . "Thousands of veterans, unable to find employment and unsettled about their future, had regarded the organization as a means of obtaining jobs or bounties. . . . After their curiosity was satisfied, they allowed their names to be dropped from the rolls" (Dearing 1952, 128). Disgruntled, veterans left the GAR, but individual claimants for pensions or bounty adjustments were still quite vocal and they actively sought help from claims agents. Even as Union veterans' interest in pensions ran high, in the late 1860s and through much of the 1870 s the GAR remained a marginal group.

\section{Filing a Pension Claim and Getting a Military Pension}

Lemon's success with the membership pool was directly related to the inefficiencies in the Pension Bureau. The Pension Bureau proved to be especially vulnerable to the turmoil of post-Civil War politics. President Andrew Johnson and his rival radical Republicans in Congress fought for control of the Bureau. Johnson had fired numerous pension agents that were "too radical" and replaced them with Democrats. In 1866, Congress retaliated by passing legislation requiring that all Johnson appointees resign within thirty days and that all new appointments be approved by the Senate. This turmoil slowed the Bureau's ability to adjudicate claims for pensions. Securing a pension became a long, involved ordeal. By 1871, there were already fortyfour federal acts addressing Civil War pensions (Oliver 1915, 36). Not only did claimants have to know of the laws, they also had to master the technicalities involved. To file a claim for a pension, the Pension Bureau required claimants to produce evidence of enlistment, length of tenure in the service, and cause of injury or death with a doctor's stamp.

The turmoil in the Bureau combined with the difficulty of securing adequate records of service caused many claims to remain incomplete. Evidence for claims trickled in, veterans sought special waivers, and relatively few initiated claims resulted in a pension for the claimant. Though claims often took more than five years to process, in 1868 the Bureau placed a three year limit on all claims in contention and a five year limit for filing for a claim subsequent to one's discharge to reduce its backlog. The Bureau attempted to regain efficiency by limiting service.

The veterans' frustration with the Bureau's inefficiency and perceived unfairness was conveyed to the House. House members were besieged with petitions asking for help in the expedition of claims or for inclusion in a 
private pension bill. As more and more members sought claims for their constituents, the House Committee on Claims became increasingly powerful. "The Chairmanship of the Committee on Claims was with two or three exceptions the most important position in the House. . . . [H] is judgment became . . law" (Representative George F. Hoar (R-MA) quoted from Thompson 1985, 213). Private legislation provided some relief for the veterans, but legislators came to feel overburdened and unduly pressured. Credit claiming aside, private legislation was too time consuming. Those legislators who could afford it often hired private assistants to help with the backlog of petitions (McMurry 1922, 28). Even the special night sessions were unable to eliminate the backlog since as many as four thousand private pension bills could be introduced in a six month period (Bensel 1984).

The claims process in the Bureau and the calendar for private legislation in the House were both noted by their crowdedness. This crowding effect fostered competition among claimants seeking the same services. The expected utility of one's own claim depended in part on the length of time it took to secure the pension, which depended on how many other claims were competing for the same limited services. As long as the pool of potential claimants remained large and the ability to respond to claims remained limited, the crowding effect persisted. The crowding effect reduced the number of new claims filed because some claims were just not worth filing as competition diminished their expected value. ${ }^{8}$ As it was operated, "the pension distribution process inevitably fostered competition among members of what was actually a single, common-interest clientele" (Thompson, 1985, 259 , emphasis in the original). ${ }^{9}$

\section{The Role for Claims Agents}

Each claim for a pension or bounty adjustment required numerous official forms called blanks or vouchers. The government had no easy means to distribute these forms to potential pensioners or to disburse the funds approved for pensions. In addition, there were few government officials assigned to explain the intricacies of the pension process. Private claims agents like Lemon filled the gap. Claims agents distributed the necessary blanks, monitored the progress of filed claims, and until 1870 were largely responsible for the disbursement of the pension money itself. For their efforts, claims agents received a set fee from the claimant (as determined by the government).

There was plenty of room for intrigue as the country was "advertised and drummed . . . by claims agents in pursuit of persons who had honest claims, or those who were willing, given that it would cost them nothing 
unless they won their pensions, to file claims that had no merit, leaving it to the ingenuity and cupidity of their agents to 'work' the cases through" (Glasson 1918, 149). One popular commentator of the time expressed widely felt outrage when he wrote that "Everybody who was morally anybody looked askance at claimhunting" (DeForest 1961, 410); but no one had an incentive to restrict honest or fraudulent claims. The claims agents would lose their contingency fee, elected officials would lose the good will of a voter, and of course the claimants themselves would lose their pensions. In 1874 , Bureau officials estimated that nearly 40 percent of approved claims were fraudulent (Oliver 1915, 40).

Fraud, however, was not the only way, or even the easiest way, for claims agents to make money. Claims agent George E. Lemon noted the unnatural competition among filed claims and was very critical of the GAR for refusing to represent pensioners. Lemon broke away from the GAR, and with a handful of other agents formed the Pensioners' Committee. At least ostensibly, the Pensioners' Committee represented the common concerns of all pensioners. The Committee orchestrated various petition drives, published the National Tribune, a barely disguised organ for the interests of the pensioners and their agents that became one of the country's most widely circulated newspapers, and warned members of Congress of their ability to control a large bloc of voters. ${ }^{10}$

The Committee's first success was the lengthening of the grace period during $\%$ hich claims could be filed from five to ten years. The most important goal for the Committee, however, was the passage of an arrears act, stipulating that pensions be paid from the time of discharge or death rather than from the time of the acceptance of the claim. Pensioners and potential pensioners alike favored such an act. President Rutherford Hayes signed the Arrears Act of 1879 , providing an average arrears payment of around one thousand dollars. The Arrears Act increased the expected value of claims yet to be filed because it extended the number of years covered thereby significantly increasing the face value of pensions. The number of claims filed in 1879 was almost double the number in 1878 , and the number of claims filed in 1880 was over 2.5 times the 1879 level. Potential claimants responded to the opportunity for personal gain, increasing the number of applications from 25,000 in 1878 to 138,000 just two years later. Lemon's entrepreneurial lobbying and grassroots activity induced favorable responses from potential claimants.

Shortly before Hayes signed the Arrears Act, the GAR developed a political wing, and Lemon rejoined making the National Tribune an organ of the GAR as well as a strong voice for claimants and pensioners. Without Lemon the Pensioners' Committee collapsed, but the revitalized GAR 


\section{Figure 1}

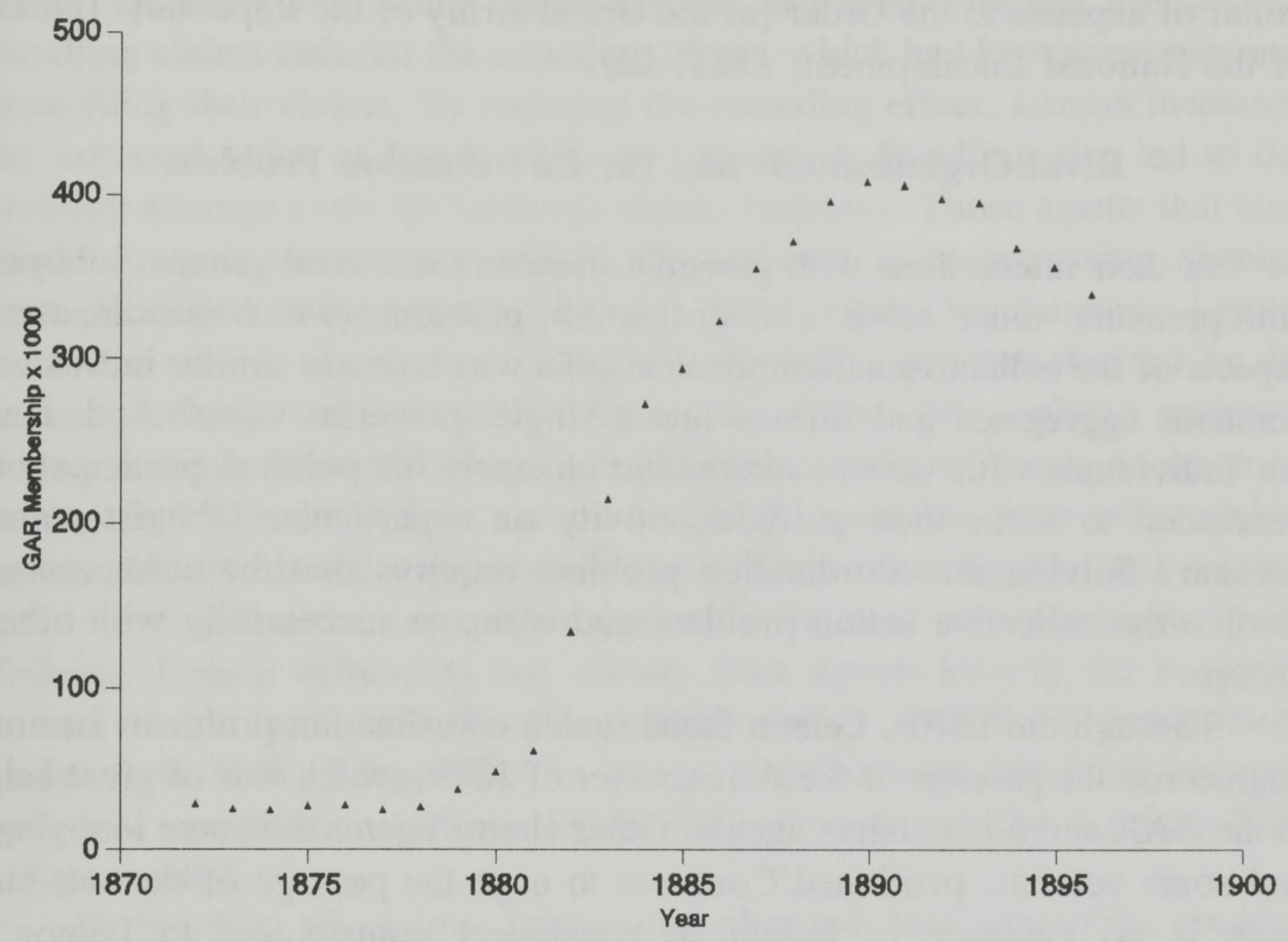

became the focal point for information about the claims process and claims agents. Though it had played no role in its passage, the GAR benefited from the Arrears Act and the increased volume in the claims business. Figure 1 shows that after a decade of declining membership in the 1870s, the GAR experienced tremendous growth after the passage of the Arrears Act. The act marked the beginning of a period of steady growth in membership during which the GAR grew from less than 40,000 members to over 400,000 . Clearly, the GAR's growth was positively affected by the passage of the Arrears Act. Veterans may have flocked to the GAR to express their gratitude for the passage of the act. Indeed, the presence of gratitude drives Hansen's (1985) analysis of group membership. However, applied to the GAR, Hansen's analysis is not persuasive. The interactions between GAR officials and GAR members revolved around concerns about the pension process. Veterans showed an uncanny interest in securing pensions. The GAR possessed considerable expertise in the area and members used the GAR to facilitate access to the pension process.

Since Lemon's successful lobbying effort to secure the passage of the Arrears Act of 1879 provided the foundation for the resurgence of the GAR, it is not surprising that the GAR officially expressed "heartfelt thanks to . . . 
George E. Lemon, for his earnest unselfish services given without one dollar of expense to the Order [of the Grand Army of the Republic]" (Notes of the National Encampment, 1883, 12).

\section{Rival Organizations and the Coordination Problem}

In their interactions with potential members and rival groups, lobbyist entrepreneurs must solve a coordination problem (which encompasses aspects of the collective action problem). To wit: how are similar individual demands aggregated and formed into a single, powerful voice? And, how are individuals with various alternative channels for political participation persuaded to focus their political activity on a particular lobbyist entrepreneur? Solving the coordination problem requires that the entrepreneur resolve the collective action problem and compete successfully with other groups.

Through the 1870s, Lemon faced such a coordination problem. Lemon engineered the passage of the Arrears Act of 1879, which was of great help to the GAR and other claims agents. Other claims agents did some lobbying, and some veterans petitioned Congress to urge the passage of the act; but there is no evidence of individual pensioners contributing to Lemon's lobbying campaign, and no other claims agent invested as much effort or money as Lemon. ${ }^{11}$ Though Lemon invested more time and money in improvements to the pension process, claimants could use any number of claims agents other than Lemon to process their claims. What made Lemon more appealing than the other claims agents offering the same goods and services? Why was Lemon unruffled by the obvious free-riding? Lemon's solutions to the free-riding and the coordination problem were intertwined.

Lemon organized his lobbying efforts so that potential members, leaders of potential rival groups, and members of Congress all focused on him. If Lemon stood out from the other claims agents, then he would receive the bulk of the new claims business generated by his lobbying efforts. Indeed, Lemon stood out for two reasons: 1) after he left the Pensioners' Committee, his close affiliation with the GAR helped him immensely by giving him a great amount of free advertising, and 2) among the claims agents, Lemon quickly developed monopoly power. A novel way of processing claims helped Lemon to achieve monopoly power. Pensioners' concerns were considered individually until Lemon represented pensioners collectively before Congress and pushed for an arrears act. In effect, Lemon rejected the narrowly focused old style of lobbying based on individual petitions and adopted a new style of lobbying that relied on claims being processed collectively. He literally bundled numerous claims, presented them en masse 
before either the House or the Bureau, and demanded their immediate resolution. Bundling was better for pensioners and more efficient for Lemon. Bundling claims reduced the crowding effect, which had kept some veterans from filing their claims. By reducing the crowding effect, Lemon increased the expected value of those claims he processed. Bundling also led to decreasing average costs for Lemon's claims business. Those agents that continued to represent claims individually suffered from increasing average costs. With decreasing average costs and better returns for claimants, Lemon became a natural monopoly. ${ }^{12}$ Natural monopolies are characterized by decreasing average costs relative to their competitors, which allows monopolies to improve their efficiency by buying out competing firms. As a natural monopolist, Lemon had no reason to fear competition from other claims agents. He purchased unprocessed claims from other agents, and secured more new claims than any other agent. In frequent advertisements in the Tribune, Lemon offered to buy claims from agents leaving the business. Lemon bought the Citizen World, a popular weekly, and 40,000 unprocessed claims from N.W. Fitzgerald, the second largest claims agent and Lemon's only real competition (Oliver 1915, 100). Lemon quickly dominated the claims market.

By bundling his claims, Lemon also changed the nature of the pressure on legislators. Legislators had fewer petitions for private pension legislation, but they also suffered from increased electoral pressure from an emerging group. Overlooking a few individual claimants was inevitable because of the crowdedness of the legislative calendar; but ignoring the demands from Lemon or the GAR had considerable electoral costs. The GAR was a large, tightly organized group, well known throughout the nation because of its control of one of the nation's most popular weekly papers. If Lemon controlled a large number of claims, he could maneuver legislation through Congress by pointing out the electoral consequences. And, the more powerful he was in Congress, the easier it was for him to increase the expected value of claims and thereby mobilize more claimants. A by-product of Lemon's lobbying efforts plan was a well established electoral connection.

\section{Electoral versus Institutional Advantages for Elected Officials}

Lemon chose both to mobilize veterans and to lobby members of Congress directly because these tactics were complementary inputs for the creation of an electoral connection. The more claimants Lemon mobilized, the easier it was for him to lobby Congress; and the more effective he was in Congress, the easier it was to mobilize more claimants. Indeed, Lemon went to great lengths to mobilize veterans. In an advertisement in the 
Tribune (3(11)(November 1879)) Lemon wrote: "I invite correspondence with all persons whose claims have been improperly rejected by the Commissioner of Pensions, as in many-I might say hundreds of instances, their rights will be speedily granted by a special appeal to Congress." Lemon promised claims for damaged crops and killed horses. Advertisements in the Tribune promised solutions to problems that some people did not know they had. The "National Tribune explains the trouble and suggests the remedy" (1(3)(December 1877):28, emphasis added).

Legislators were aware of the electoral influence of Lemon and the increasingly aggressive GAR. In the National Tribune, Lemon transcribed congressional debates, often showing the unsavory language used to describe greedy claimants and claims agents, and he always listed votes on key issues. Some members of Congress were so eager to have their names listed in the Tribune next to Lemon's that they wrote obsequious "letters to the editor" exclaiming the virtues of Lemon. ${ }^{13}$ Indeed, Lemon advertised in the Tribune that he had favorable references from each congressional district (1(1)(October 1878):8). Lemon's goal was clear when he wrote: "claimants demand relief, and members of Congress who wish to make 'their calling and election sure' are advised to provide a remedy" (National Tribune 1(8)(May 1878):61).

Lemon's appeals and threats were not idle. His efforts were reinforced by the simple fact that many congressional districts had numerous pensioners and potential pensioners, and there is evidence that the soldiers' vote affected the outcome of both presidential and congressional races. Glasson attributes Grover Cleveland's failed 1888 reelection bid to his veto of the 1887 Dependent Pension Bill (Glasson 1918, 225). Glasson reasoned as follows. In 1884, Cleveland carried Indiana by just over one thousand votes and his native New York by sixty-five hundred votes. In 1888, Cleveland lost New York by over thirteen thousand votes, even as New York elected a Democratic governor by a nineteen thousand vote margin. New York's forty-five thousand pensioners were clearly a large enough bloc to make the difference. Indiana had thirty-eight thousand pensioners in 1888, and Cleveland lost it by only twenty-three hundred votes. ${ }^{14} \mathrm{~A}$ win in either state would have secured the presidency for Cleveland.

Similar electoral impact was felt in both houses at the congressional level (Glasson 1918, 162, 205; Dearing 1952, 248-249). The GAR's penchant for electoral retaliation revealed itself most clearly in their attack on Representative Adoniram Warner (D-Ohio). The GAR's Committee on Pensions had testified before the House's Pensions, Bounty, and Back Pay Committee, which Warner chaired. Thinking that they had received clear assurances from Warner on key proposals, the GAR's Committee on Pensions 
was surprised by legislation reported by Warner. The GAR decided to retaliate in the 1886 election. In a widely circulated letter (later published in the Congressional Record), a member of the GAR's Committee on Pensions wrote that

Gentlemen like Mr. Warner must be taught that it is not to prove safe to play with soldiers' interests in the committee-rooms and on the floor of the house.

Every soldier in that Congressional district owes it to the large number of his needy and suffering comrades . . . to make an example of Warner and terminate his Congressional career now (McMurry 1922, 22-23).

Given this electoral environment, some legislators clearly wanted to reduce their vulnerability to the soldiers' vote. Speaking of the 1887 Dependent Pension bill, Representative Edward S. Bragg (D-WI, and a Union veteran) recognized and indicted the electoral connection when he said "'The men who advocate this bill are not ... the friends of the soldier. . . . They advocate the bill, why? Simply because the men whom they expect to buy by the bill can vote'" (Glasson 1918, 215).

As the electoral connection became stronger, other actors (in particular parties and elected officials) had incentives to invest in its preservation. Once an electoral connection is established, the entrepreneur controls a valuable linkage. Moe (1980) notes the usefulness of the communication link between the interest group entrepreneur and the membership. This "link with members can become useful to other individuals and . . . [the entrepreneur] can charge . . . a fee in return for access to it" (Moe 1980, 42). Indeed, presidential candidates and other prominent politicians sought speaking engagements at the GAR's National Encampments and at state meetings. Each new Congress had its own proponents for increased pensions. After the Arrears Act of 1879, the greatest liberalization occurred in 1890 but other liberalizations occurred in 1907, 1911, and 1912. As qualifications for a pension became more and more lax, the electoral connection became stronger and increased liberalizations came easier. The 1890 legislation awarded pensions for disabilities that were not of service origin. The GAR admitted that the bill was designed to include "all survivors of the war whose conditions of health . . . [were] not practically perfect" (Glasson 1918, 237). By 1907 , pension legislation covered anyone who had served for 60 days or longer. In 1911, pension bills from each party promised greater pensions than the GAR requested. In 1912, pensions were automatic when soldiers reached the age of 62 . The members of each new Congress had to increase pensions and liberalize qualifications if they were to maintain their own profits from the electoral connection. 
Sometimes the payments followed the four-year electoral cycle. The most blatant example occurred just before the 1884 presidential race between Grover Cleveland and James G. Blaine. On average, 1600 claims were resolved each month through most of 1884. In September and October, 4400 claims were resolved each month (Oliver 1915, 77). In addition, extra field agents with the names and addresses of pensioners and veterans were sent to key states with evenly split partisanship. Republican House candidates sent the names of wavering voters to these field agents so they could expedite claims. Sanders (1980) found that pensions often improved Republican turnout.

By passing increasingly generous pension legislation, legislators benefited in two distinct ways. Though some legislators simply sought an electoral advantage, legislators also secured an institutional advantage because with key liberalizations there was a dramatic drop in the need for private pension acts (which often accounted for a third to a half of the total number of all congressional acts during this period). The relaxed qualifications in comprehensive pension legislation meant that legislators could limit their direct involvement in pension matters and free the legislative calendar. By limiting their direct involvement, members secured even greater credit claiming capabilities because more voters received pensions and because as legislators they could still intervene in special cases. The increased liberalizations benefited everyone involved. Pensioners and Lemon profited directly. Legislators freed their legislative calendar, felt less pressure to pass private pension bills, enhanced their credit claiming opportunities, and very likely benefited electorally.

Many scholars argue that legislators' desires to delegate are driven by electoral considerations or a general unwillingness to make difficult choices (e.g., Kiewiet and McCubbins 1991). No doubt, both of those considerations had some impact, but delegation of pension matters also freed an amazingly burdened legislative calendar, and thereby allowed members to address other equally important issues. As Figure 2 shows, the number of private pension acts immediately after the 1879 act was reduced by half, and the reduction after the 1890 act was even greater. Although there was a general growth in the number of private pension acts during this period, the constraints on the legislative calendar were dramatically lessened in the short term by the liberalized pension legislation.

"Lemon divided his fulminations between appeals to the veterans and threats to the parties" and legislators (Dearing 1952, 250). Neither tactic alone would have been as valuable without the other, neither tactic alone could have created an electoral connection or yielded such direct institutional advantages for legislators. Neither tactic alone could have resulted in 


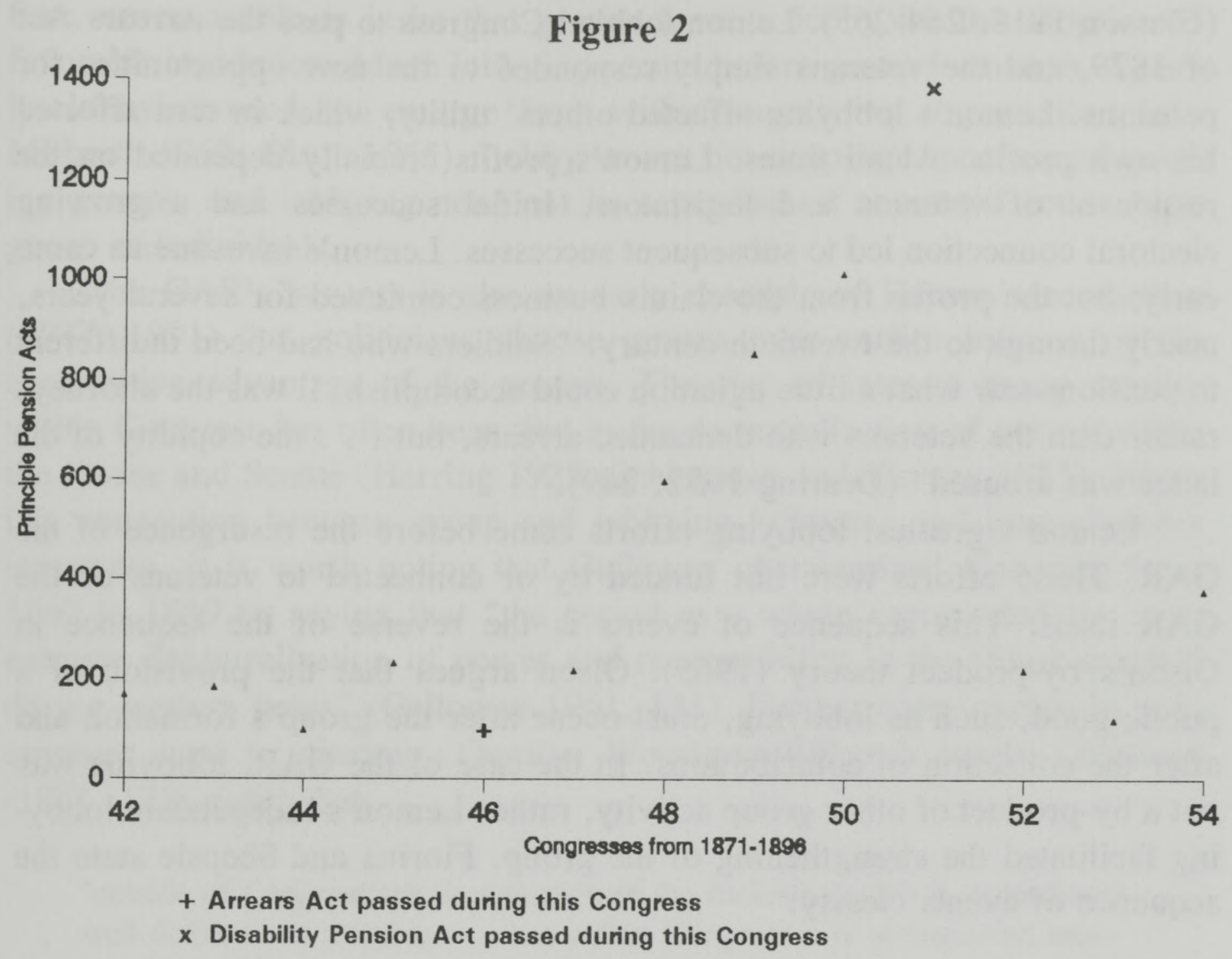

Lemon's personal success. ${ }^{15}$ Lemon interceded on the behalf of pensioners and placed himself in such a position to profit from the electoral connection that he developed and that others maintained. Politicians were not simply subject to pressure from the veterans or the GAR; indeed, they supported and strengthened the nascent electoral connection and then became subject to it. Recall that in the late 1860s the Republican party denied Logan's requests for money for the GAR, but by the 1880 s politicians competed to address GAR meetings.

\section{Discussion}

To what extent were Lemon and the veterans in cahoots? As an entrepreneur, Lemon initiated the pressure for more liberal pensions and then relied on rational responses from the individual veterans. Though they shared attitudes (ala Truman 1951) and responded similarly to incentives to file for a pension or to join the GAR, the veterans did not, per se, act in concert. The veterans themselves engineered nothing. "The self-seeking spirit . . . of soldiers was not spontaneous. . . . It was systematically cultivated by so-called 'friends of the soldiers'-claims agents and politicians" 
(Glasson 1918, 264-265). Lemon lobbied Congress to pass the Arrears Act of 1879 , and the veterans simply responded to the new opportunities for pensions. Lemon's lobbying affected others' utility, which in turn affected his own profits. At all times, Lemon's profits crucially depended on the responses of veterans and legislators. Initial successes and a growing electoral connection led to subsequent successes. Lemon's investments came early; but the profits from the claims business continued for several years, nearly through to the twentieth century. "Soldiers who had been indifferent to pensions saw what a little agitation could accomplish. It was the attorneys rather than the veterans who demanded arrears, but . . . the cupidity of the latter was aroused" (Dearing 1952, 249).

Lemon's greatest lobbying efforts came before the resurgence of the GAR. These efforts were not funded by or connected to veterans or the GAR itself. This sequence of events is the reverse of the sequence in Olson's by-product theory (1965). Olson argues that the provision of a public good, such as lobbying, must occur after the group's formation and after the collection of contributions. In the case of the GAR, lobbying was not a by-product of other group activity, rather Lemon's independent lobbying facilitated the strengthening of the group. Fiorina and Shepsle state the sequence of events clearly:

many political agents must first set up their principal. The agent as entrepreneur must create her interest group, construct her constituency, or build her coalition before she can reap the rewards. . . . But this most fundamental aspect of leadership has not received a satisfactory treatment in the PE [political entrepreneur] literature precisely because of a failure to incorporate the strategic calculations of followers (Fiorina and Shepsle 1989, 37).

This sequence also insures that followers do not have to worry about the "take the money and run" problem (cf., Frohlich, Oppenheimer, and Young 1971). That is, the leader or lobbyist entrepreneur has no money from the members with which to abscond. Contributions come after the investment, not before. Although the sequence is similar to that in Hansen's analysis (1985), the reasoning is different. Hansen argues that grateful individuals join a group after the provision of a public good; but Hansen's analysis ignores the freerider problem. Here, the GAR's facilitative role in securing pensions provided the key impetus for membership.

The rejuvenation of the GAR after the passage of the 1879 legislation parallels some of findings in Costain's (1992) and Walker's work (1983) on the formation of interest groups. Walker (1983) found that half of the interest groups addressing issues for the elderly came into existence after (rather than before) the passage of the Older Americans Act of 1965. It is, there- 
fore, unreasonable to insist that groups form to lobby for the adoption of favorable legislation. Much lobbying occurs before group formation. Clearly, lobbyists need not emerge from within an existing organization (cf., Milbrath 1963; Olson 1965). Lobbyists are not simply phenomena of existing groups, and lobbying need not be a product of concerted action by a group of individuals.

The GAR's success is also an early example of Hansen's contention $(1987 ; 1991)$ that politicians choose groups over parties because of the competitive advantage of the groups. The rise of interest group activity within Congress has often been tied to the decentralization of power within the House and Senate (Herring 1929; Schlozman and Tierney 1983). Given this connection between group and lobbying influence and intra-chamber structures, it is worth noting that Galloway characterized Congress from 1860 to 1889 by saying that "the period as a whole represented the most extreme decentralization of power and responsibility in the House reached during modern times" (Galloway 1961, 131). Furthermore, parties in government were in disarray. Quoting Woodrow Wilson's work, Galloway $(1961,131)$ noted that

'outside of Congress the organization of the national parties is exceedingly well-defined and tangible . . . but within Congress it is obscure and intangible. . . . [T]heir discipline is very slack and indefinite. . . A At least there is within Congress no visible, and therefore no controllable party organization' (italics in the original).

This disarray is evidenced in a couple of ways on pension issues. First, petitions for private bills overwhelmed each chamber. The private calendar became so crowded that there was little time for other matters. Party leaders were unable to protect the legislative calendar or address the workload issue. Neither party was able to provide relief from the electoral pressures of pensioners, nor could they find another issue that so readily mobilized voters. ${ }^{16}$ The GAR designed the pension legislation during the late nineteenth century that relieved the legislative calendar and reduced the member's workload for casework without making them suffer electorally. Even as it wielded great influence over legislators, the GAR was also integral to an electoral connection that provided valuable benefits to veterans and legislators. Though members were electorally vulnerable to the GAR's ability to mobilize voters, the GAR's involvement in both legislative and bureaucratic affairs actually made legislators' intra-chamber lives easier. In that sense, the GAR and the electoral connection stemming from it supplanted both political parties. 


\section{Conclusion}

By itself, an analysis of interest group entrepreneurship is not novel; but unlike earlier work concentrating on entrepreneurial efforts in limited arenas, I have analyzed Lemon's strategic interactions across three distinct arenas within which lobbyist entrepreneurs operate. The connections across these arenas are complex. Entrepreneurs expending efforts in one arena (e.g., by directly lobbying legislators) must rely on the rational responses of individuals in the other arenas (e.g., veterans filing claims). Therefore, lobbyists, as entrepreneurs, profit indirectly from their efforts-if at all. Of course, if the electoral connection is strong, then the entrepreneur's interest group can readily survive long after the initial "disturbance" that the entrepreneur first exploited.

Historical analysis provides a perspective on more recent findings, either supporting or undermining them in the process. Studying interest groups and lobbying from around the turn of the century can yield insights into the growth of lobbying, the emergence of interest groups, and the role of entrepreneurs in the interest group environment. Throughout the paper, parallels (and disparities) between results here and results from other scholars' analyses of more recent group activity were drawn. In particular, "shared attitudes" and "claims upon others" were clearly not sufficient for the establishment or survival of the GAR (cf., Truman 1951). Indeed, shared attitudes and claims upon others led to competition among the claimants as the Pension Bureau and the legislative calendar became crowded. In addition, lobbying was the essential tool for the creation of the GAR, rather than a "by-product" (cf., Olson 1965). Successful interest group entrepreneurship may rely on successful interaction with members of Congress, rival groups, and prospective group members-rather than coercion within the group or the charismatic qualities of a group's leadership.

If lobbyists of the late 1800 s were so enterprising, why are they now so often seen as ineffectual (e.g., Bauer, Pool, and Dexter 1968)? The majority of lobbyists today are not lobbyist entrepreneurs; they are lobbyists hired-sometimes generations after a group's formation-to maintain an organization. Lobbyists in charge of maintaining an organization more frequently monitor (rather than write) legislation and augment member's staffs (rather than demand members' time). These lobbyists are hired for their professional managerial skills, not for their entrepreneurial ingenuity. In Hardin's terms (1982), they simply maintain the "contracts by conventions" that others first coordinated.

Results from this work suggest that lobbyist entrepreneurs must master the intricacies of delegation. That is, the successful lobbyist entrepreneur 
must recognize opportunities for delegation from individual constituents to the group and from legislators to bureaus and groups. Indeed, for the group's linkage function to remain viable, there must be delegation from members to the group and from legislators to the group and bureaus. Further study of delegation and the linkage functions of interest groups should prove fruitful.

\section{NOTES}

Though numerous individuals have commented on aspects of this project, I would like to thank Chuck Bullock, John Clark, Vally Koubi, Jerry Legge, Brad Lockerbie, John Maltese, and Susan Nees for their comments and assistance on this most recent version. Dan Brill and Douglas Hanson provided invaluable research assistance. Special thanks also go to Gary Wekkin and four anonymous reviewers for The American Review of Politics. Their suggestions have made this a much better paper. The usual caveats apply.

${ }^{1}$ One of the best works on interest representation in the late 1800s is by Thompson (1985). There is also work analyzing the effects of firms and economic pressure groups in the 1800s on tariff legislation (Pincus 1975). Of course, there are numerous studies of the Grange. Recent work by Ainsworth and Maltese (Forthcoming) examines the Grange's lobbying activities surrounding Supreme Court nominee Stanley Matthews. Brown (1992) provides a nice overview of the early years of the National Rifle Association. See Petracca (1992) for a list of additional work.

${ }^{2}$ The Grand Army of the Republic (GAR) maintained detailed records, keeping track of key membership data. Newspapers and writers of the time followed the activities of the GAR closely. In addition, the U.S. government's Pension Bureau recorded data on the number of pensioners and claimants affected by various pieces of legislation. Given the focus on an interest group that reached its peak in influence about one hundred years ago, these are amazingly good data sources.

${ }^{3}$ Recent studies have analyzed the geo-political effects of the GAR (e.g., Bensel 1984 , Ch. 3) or theorized about the connections between military pensions and the rise of the welfare state (Skocpol and Ikenberry 1983; Skocpol 1992, Ch. 2; Quadagno 1988, Ch. 3). Scholars focusing more tightly on the GAR itself have explored the connections between the Republican party and the GAR (e.g., Dearing 1952) or the social history of the GAR (McConnell 1992). Here, the focus is on the strategic interactions between GAR members and potential members, a lobbyist entrepreneur, and government officials.

${ }^{4}$ The impact of a group's electoral connection is related to legislators' reelection motivations and the presence of careerism in the legislature, both of which were perhaps weaker during the late 1880s than at present (cf., Kernell 1977). Careerism was weakened by the practice of rotation and the fact that Congress was less institutionalized, offering scant resources to its members. However, this period also marks the beginning of important changes in the electoral fortunes of members. Garand, Wink, and Vincent (1993, Table 2) show that by the mid-1870s the defeat rates for House incumbents were declining. Kernell (1977) notes that the decline in turnover started around 1870. Incumbents were more likely to run for reelection and were more successful at retaining their 
seat. In addition, McMurry (1922), Dearing (1952) and others refer to the growing number of "professional vote getters" during this period. Though I am not prepared to argue that 19th Century legislators were as reelection motivated as today's, there was a movement in that direction. More direct tests of the electoral connection are made in Ainsworth (1995).

${ }^{5}$ There are numerous conceptions and definitions of lobbyists. There are three general types of lobbyists commonly portrayed in current interest group literature: i) One can lobby for the narrow concerns of an individual institution or firm. There is good reason to suspect that this type of lobbying dominates much of the lobbying activity in Washington (Salisbury 1984). ii) One can lobby for a broadly based interest group. The success of this type of lobbying is affected by the freerider problem, which highlights the importance of lobbyists' entrepreneurial efforts. iii) Finally, one can lobby for the maintenance of an interest group. This final type of lobbying is much more defensive than the first two. Events are more apt to be monitored rather than affected. There are numerous differences between lobbying for institutions, lobbying for nascent mass organizations, and lobbying for the maintenance of established organizations. In each situation, the role of the lobbyist is different and the reactions from government officials, group members, potential members, and rival groups are different.

${ }^{6}$ Smith (1988) uses the terms "old style" and "new style" to describe lobbying strategies in the twentieth century. His usage is not consistent with Herring's.

${ }^{7}$ Though some individual Republicans maintained contact with their local GAR posts, it was only to insure their immediate electoral success. Logan's use of the GAR is especially illustrative. Logan joined in 1866, headed the organization from 1868 through 1870 , was dropped from the rolls in 1872 because he failed to pay his dues, and finally rejoined around 1881 when the GAR reemerged as a powerful political force.

${ }^{8}$ Some public goods are vulnerable to crowding effects, which diminish their value to any one individual. For example, public beaches are prone to a crowding effect if too many users diminish the value of the beach for any one user. This same sort of crowding effect reduced the expected utility of a pension claim.

'The contrast to Truman (1951) is striking. For Truman, shared attitudes and claims upon others were defining attributes of a group. Here, shared attitudes and claims upon others exacerbated the crowding effect and created competition among the claimants.

${ }^{10}$ See Glasson $(1918,150$, fn 1, passim), Dearing (1952, passim), and Thompson (1985, 260-261, passim) for more information on the National Tribune.

${ }^{11}$ R.A. Dimmick was also quite active in the Pensioners' Committee and the passage of the Arrears Act. Dimmick even claimed sole responsibility for the passage. In widely distributed circulars, Dimmick asked for contributions from other claims agents and pensioners to help defray his costs. Congress barred Dimmick from prosecuting claims for loose talk about bribing members of Congress and for perjury before the House (Glasson 1918, 157, fn 1).

${ }^{12}$ The affect of an organization's size on its costs is usually posited to be just the opposite (e.g., Olson 1965). That is, larger groups are considered to be more difficult and more costly to organize.

${ }^{13} \mathrm{See}$, for example, the letters of Congressmen Hurlbut, Sprague, and Strawbridge (National Tribune 1(1)(October 1878):8). 
${ }^{14}$ Cleveland's attempts to reduce the tariff and his attacks on Tammany Hall proved to be divisive within his Democratic ranks, which certainly hurt his cause.

${ }^{15}$ No doubt, Lemon died a wealthy man. Just after the passage of the Arrears Act, he made as much as 40,000 dollars a month.

${ }^{16}$ Proponents of the tariff, the other important issue during the late $1800 \mathrm{~s}$, often connected their support for higher tariffs to the need to fund pensions.

\section{REFERENCES}

Ainsworth, S. 1995. Electoral Strength and the Emergence of Group Influence in the Late 1800s: The Grand Army of the Republic. American Politics Quarterly 23:319338 .

Ainsworth, S., and J.A. Maltese. Forthcoming. National Grange Influence on the Supreme Court Confirmation of Stanley Matthews. Social Science History.

Ainsworth, S., and I. Sened. 1993. The Role of Lobbyists: Entrepreneurs with Two Audiences. American Journal of Political Science 37:834:-866.

Arnold, R.D. 1982. Overtilled and Undertilled Fields in Political Science. Political Science Quarterly 97:91-103.

Bauer, R.A., I.de S. Pool, and A.L. Dexter. 1968. American Business and Public Policy. New York: Atherton Press.

Bensel, R.F. 1984. Sectionalism and American Political Development: 1880-1980. Madison: University of Wisconsin Press.

Brown, C. 1992. Modeling Membership in the National Rifle Association. Midsouth Journal of Political Science 13:157-172.

Brown, C., and R. Jankowski. 1994. Political Success, Government Subsidization and the Group Freerider Problem. Mimeo. Miami University.

Clark, P.B., and J.Q. Wilson. 1961. Incentive Systems. Administrative Science Quarterly 6:219-266.

Costain, A.N. 1992. The Women's Movement. In M.P. Petracca, ed., The Politics of Interests. Boulder: Westview Press.

Dearing, M.R. 1952. Veterans in Politics. Baton Rouge: Louisiana State University Press.

DeForest, J.W. 1961. Playing the Mischief. State College, PA: Bald Eagle Press. Originally published in 1875 .

Fiorina, M.P., and K.A. Shepsle 1989. Formal Theories of Leadership: Agents, Agenda Setters, and Entrepreneurs. In B.D. Jones, ed., Leadership and Politics. Lawrence: University of Kansas Press.

Frohlich, N., J. Oppenheimer, and O. Young. 1971. Political Leadership and Collective Goods. Princeton: Princeton University Press.

Garand, J.C., K. Wink, and B. Vincent. 1993. Changing Meanings of Electoral Marginality in U.S. House Elections, 1824-1978. Political Research Quarterly 46:27-48.

Glasson, W.H. 1918. Federal Military Pensions in the United States. New York: Oxford University Press.

1900. History of Military Pension Legislation in the United States. Vol. XII of Studies in History, Economics and Law; New York: AMS Press. 
Hansen, J.M. 1991. Gaining Access. Chicago: University of Chicago Press. 1987. Choosing Sides. Studies in American Political Development 2:183-229. 1985. The Political Economy of Group Membership. American Political Science Review 79:79-96.

Hardin, R. 1982. Collective Action. Baltimore: The Johns Hopkins University Press.

Herring, E.P. 1929. Group Representation Before Congress. Baltimore: The Johns Hopkins University Press.

Journal of the Nineteenth Annual Session of the National Encampment, Grand Army of the Republic, 1885.

Kernell, S. 1977. Toward Understanding 19th Century Congressional Careers: Ambition, Competition, and Rotation. American Journal of Political Science 21:669-693.

Kiewiet, D.R., and M.D. McCubbins. 1991. The Logic of Delegation. Chicago: University of Chicago Press.

McConnell, S. 1992. Glorious Contentment. Chapel Hill: University of North Carolina Press.

McMurry, D.L. The Political Significance of the Pension Question, 1885-1897. Mississippi Valley Historical Review 9:19-36.

Milbrath, L.W. 1963. The Washington Lobbyists. Chicago: Rand McNally and Company.

Moe, T.M. 1980. The Organization of Interests. Chicago: University of Chicago Press.

National Tribune. Various dates.

Notes of the National Encampment of the Grand Army of the Republic, 1883.

Oliver, J.W. 1915. History of the Civil War Military Pensions, 1861-1885. Ph.D. Dissertation, University of Wisconsin.

Olson, M. 1965. The Logic of Collective Action: Public Goods and the Theory of Groups. Cambridge: Harvard University Press.

Petracca, M.P. 1992. The Rediscovery of Interest Group Politics. In M.P. Petracca, ed., The Politics of Interests. Boulder: Westview Press.

Pincus, J.J. 1975. Pressure Groups and the Pattern of Tariffs. Journal of Political Economy 83:757-778.

Quadagno, J. 1988. The Transformation of Old Age Security. Chicago: University of Chicago Press.

Salisbury, R.H. 1969. An Exchange Theory of Interest Groups. Midwest Journal of Political Science 13:1-32.

1984. Interest Representation: The Dominance of Institutions. American Political Science Review 78:64-76.

Sanders, H.T. 1980. Paying for the 'Bloody Shirt.' In B.S. Rundquist, ed., Political Benefits. Lexington, MA: Lexington Books.

Schlozman, K.L., and J.T. Tierney. 1983. More of the Same: Washington Group Activity in a Decade of Change. Journal of Politics 45:351-375.

Skocpol, T. 1992. Protecting Soldiers and Mothers. Cambridge: Harvard University Press.

Skocpol, T. and J. Ikenberry. 1983. The Political Formation of the American Welfare State in Historical and Comparative Perspective. In Richard S. Thomasson, ed., Comparative Social Research: The Welfare State. Vol. 6; Greenwich, CT: JAI Press.

Smith, H. 1988. The Power Game. New York: Random House. 
Stewart, C. III. 1989. Budget Reform Politics. Cambridge: Cambridge University Press.

Sundquist, J.L. 1981. The Decline and Resurgence of Congress. Washington, D.C.: The Brookings Institution.

Thompson, M.S. 1985. The 'Spider Web:' Congress and Lobbying in the Age of Grant. Ithaca: Cornell University Press.

Truman, D.B. 1951. The Governmental Process. New York: Knopf.

Walker, J.L. 1983. Origins and Maintenance of Interest Groups in America. American Political Science Review 77:390-406.

Wilson, J.Q. 1973. Political Organizations. New York: Basic Books. 